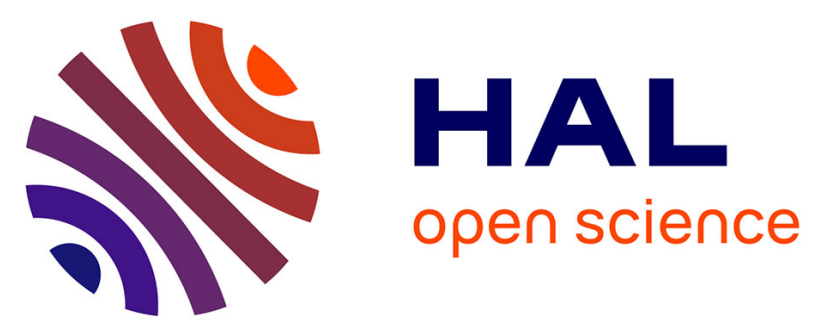

\title{
New approach in determining absorption coefficients of strongly absorbing liquids : optothermal studies on sunflower oil, oleic acid (and its chloroform solutions) at 3.39 microns
}

D. Bicanic, M. Chirtoc, I. Chirtoc, B. van Veldhuizen, J. Favier, P. Helander, J. Harryvan, J. Cozijnsen, M. Lubbers

\section{To cite this version:}

D. Bicanic, M. Chirtoc, I. Chirtoc, B. van Veldhuizen, J. Favier, et al.. New approach in determining absorption coefficients of strongly absorbing liquids: optothermal studies on sunflower oil, oleic acid (and its chloroform solutions) at 3.39 microns. Journal de Physique IV Proceedings, 1994, 04 (C7), pp.C7-487-C7-490. 10.1051/jp4:19947114 . jpa-00253167

\section{HAL Id: jpa-00253167 https://hal.science/jpa-00253167}

Submitted on 1 Jan 1994

HAL is a multi-disciplinary open access archive for the deposit and dissemination of scientific research documents, whether they are published or not. The documents may come from teaching and research institutions in France or abroad, or from public or private research centers.
L'archive ouverte pluridisciplinaire HAL, est destinée au dépôt et à la diffusion de documents scientifiques de niveau recherche, publiés ou non, émanant des établissements d'enseignement et de recherche français ou étrangers, des laboratoires publics ou privés. 


\title{
New approach in determining absorption coefficients of strongly absorbing liquids: optothermal studies on sunflower oil, oleic acid (and its chloroform solutions) at $\mathbf{3 . 3 9}$ microns
}

D. Bicanic, M. Chirtoc*, I. Chirtoc*, B. van Veldhuizen**, J.P. Favier, P. Helander***, J. Harryvan****, J. Cozijnsen $* * * * *$ and M. Lubbers*******

Laser Photoacoustic Laboratory, Department of Agricultural Engineering and Physics, Agricultural University, Bomenweg 4, 6703 HD Wageningen, The Netherlands

* Institute for Isotopes and Molecular Technology, P.O. Box 700, 3400 Cluj-Napoca, Romania

** Department of Organic Chemistry, Agricultural University, Dreyenplein 8, 6703 HB Wageningen, The Netherlands

*** AB Varilab, Fullerstavägen 32, 14144 Huddinge, Sweden

**** Department of Human Nutrition, Biotechnion, Agricultural University, Bomenweg 2,

6703 HD Wageningen, The Netherlands

***** Department of Food Science, Agricultural University, Biotechnion, Bomenweg 2,

6703 HD Wageningen, The Netherlands

****** Department of Soil Science and Geology, Agricultural University, Duivendaal 10 ,

670I AR Wageningen, The Netherlands

\begin{abstract}
Large values (nearly $3000 \mathrm{~cm}^{-1}$ ) of absorption coefficients $\beta$ (unaccessible by conventional spectrometric methods), were measured for pure monounsaturated oleic acid (C18:1) at $3.39 \mu \mathrm{m}$ (C-H stretch vibration) using He-Ne laser in combination with a novel, compact optothermal sensor. Failure (except in a low concentration range) of $\mathrm{C}-\mathrm{H}$ stretch vibration to follow Lambert-Beer's law was observed for solutions of C18:1 in chloroform. At $3.39 \mu \mathrm{m}$ minimum detectable concentration of $\mathrm{C} 18: 1$ in chloroform is $0.35 \%$.
\end{abstract}

\section{INTRODUCTION}

In traditional infrared (IR) transmission spectrometry liquids are normally examined either neat (a film ( $<10 \mu \mathrm{m}$ thick) compressed between two flat windows and held together by the capillarity) or in solution [1]. Thick layers of neat liquids absorb too strongly to produce a satisfactory spectrum. Large (IR) absorption coefficients $\beta$ of edible oils and triglycerides, as well as unability of experimentalist to exactly specify the effective pathlength are major factors precluding performance of quantitative studies with these samples. Oil chemists and nutritionists prefer therefore new methodologies and a low cost, practical instrument that would not only allow measurements of high $\beta$ values (approximately $3000 \mathrm{~cm}^{-1}$ ) of pure compounds in a simple and reproducible fashion, but also enable determination of small amounts of such samples diluted in various solvents without a need to know the sample's thickness.

In this paper results of an experiment carried out with an optothermal window (OW) in IR are presented. Samples (pure and dissolved in chloroform) of monounsaturated oleic $\left(\mathrm{C}_{18} \mathrm{H}_{34} \mathrm{O}_{2}\right)$ acid C18:1, cis (purity larger than $99 \%$ ) and of sunflower oil were used in this study. All carboxylic acids display broad and intense $\mathrm{O}-\mathrm{H}$ stretch absorption bands in region of $3300-2500 \mathrm{~cm}^{-1}$ (usually centered near 3000 $\mathrm{cm}^{-1}$; weaker $\mathrm{C}-\mathrm{H}$ stretching bands are generally superimposed upon $\mathrm{O}-\mathrm{H}$ band). The measurements were performed using a He-Ne laser (emitting $2 \mathrm{~mW}$ ) at $3.39 \mu \mathrm{m}\left(2949.5 \mathrm{~cm}^{-1}\right)$. Water, for which $\beta$ value at $3.39 \mu \mathrm{m}$ is known was used to calibrate the system. The analytical potential of optopthermal window was investigated using solutions of C18:1 in chloroform. 


\section{EXPERIMENTAL}

The recently proposed optothermal window (OW) cell [2] shown in Fig. 1 appears well suited for measuring $\beta$ of strongly absorbing fluids. Optothermal detection can be performed with arbitrary quantity of sample deposited atop a transparent sapphire window (having large thermal expansion coefficient) that is illuminated (from below) by a chopped radiation (through the very same window) of the IR He-Ne laser. The periodic heat generated in the sample due to absorption of radiation diffuses into the sapphire and leads to a formation of acoustic wave that is sensed by a piezoelectric (PZT) sensor. The lock-in amplifier (EG\&G/PAR 5101) amplifies the a.c. signal detected synchronously with the modulated radiation.

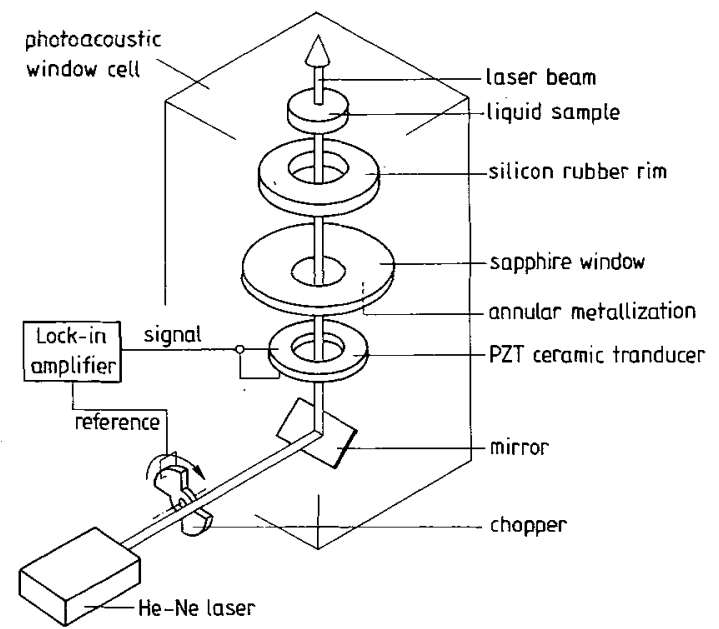

Fig. 1 Exploded view of optothermal window (OW) cell and of the experimental set up used in this study.

The amplitude of the signal depends on temperature fluctuations taking place within roughly one thermal diffusion length $\mu$ from the sample-sensor interface. It can be shown that when sample (subscript s) is both thermally and optically thick and thermally thick window (subscript $w$ ), the amplitude $S$ of optothermal signal is proportional to the expression:

$$
\mathrm{S} \sim \beta_{\mathrm{s}} \mu_{\mathrm{s}}\left[\left(1+\beta_{\mathrm{s}} \mu_{\mathrm{s}}\right)^{2}+1\right]^{-1 / 2}\left(1+\mathrm{e}_{\mathrm{s}} / \mathrm{e}_{\mathrm{w}}\right)^{-1}
$$

while phase $\phi$ is given by

$$
\phi=-\arctan \left(1+\beta_{\mathrm{s}} \mu_{\mathrm{s}}\right)^{-1}
$$

In eqs. (1) and (2) symbols $\mathrm{e}$ and $\mu$ represent thermal effusivity and thermal diffusion length defined as $\mathrm{e}=(\mathrm{k} \rho \mathrm{c})^{1 / 2}$ and $\mu=(\mathrm{k} / \pi \rho \mathrm{cf})^{1 / 2}$ where $\mathrm{k}, \rho, \mathrm{c}$ and $\mathrm{f}$ denote thermal conductivity, density, volume specific heat, and modulation frequency. If $\beta_{\mathrm{s}} \mu_{\mathrm{s}} \gg 1$ and $\mathrm{e}_{\mathrm{s}} / \mathrm{e}_{\mathrm{w}} \ll 1$, eqs. (1) and (2) give $\mathrm{S}=1$ and $\phi$ takes a zero value (optical saturation). For $\beta_{\mathrm{s}} \mu_{\mathrm{s}} \ll 1, \mathrm{~S}=\beta_{\mathrm{s}} \mu_{\mathrm{s}} /(2)^{1 / 2}$ and $\phi=-45^{\circ}$. Such linear regime is however unattainable when investigating strongly absorbing (high $\beta$ ) samples because short $\mu$ values are required to match condition $\beta \mu \gg 1$. This is turn implies a need for high modulation frequencies $\mathrm{f}$ and hence low level signals will be generated. Experiments described in this paper are performed with product $\beta_{\mathrm{s}} \mu_{\mathrm{s}}$ ranging from 0.7 to 10 .

\section{RESULTS AND DISCUSSIONS}

The specimen of C18:1 acid is a product (purity > 99\%) of Merck (art. 471); numerical values of its (and of other samples) thermophysical parameters (specified in Table 1) were taken from the 
literature $[3,4]$. Figure 2 features plots of net optothermal signal $S$ (to compensate for background effects "background" signals obtained with empty OW cell were vectorially subtracted from those measured with actual samples) for oleic acid, sunflower oil, and water within $30<\mathrm{f}<1000 \mathrm{~Hz}$ range of modulation frequencies.

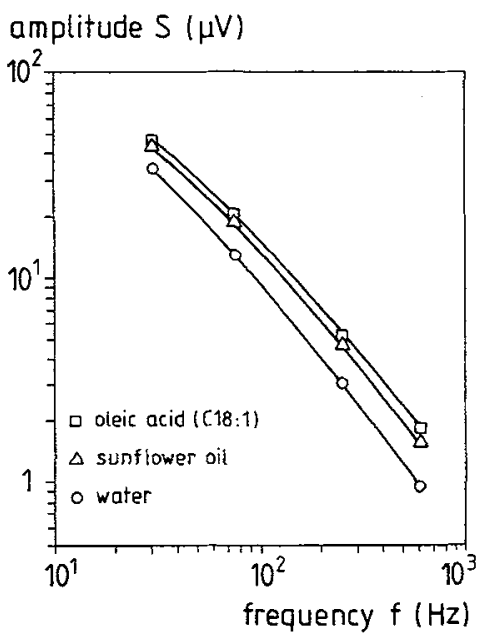

Fig. 2. The amplitude $S$ of the optothermal signal plotted versus modulation frequency f for three samples.

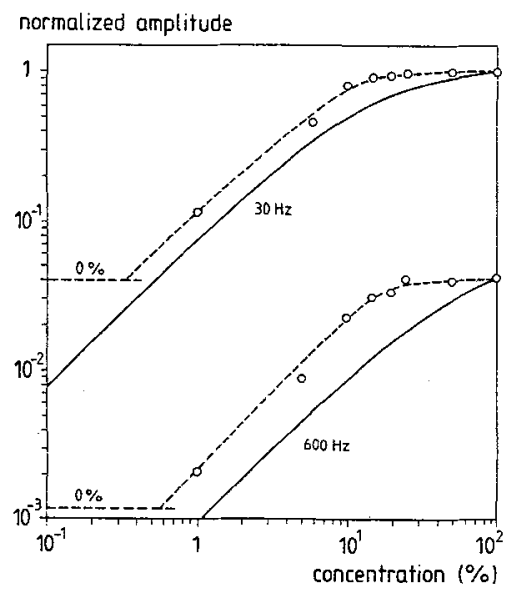

Fig. 3 Normalized optothermal signal amplitude for various concentrations of oleic acid-chloroform solutions at two modulation frequencies. Broken lines: experiment. Solid lines: theory, i.e. eq. (1).

In order to determine $\beta$ for $\mathrm{C} 18: 1$ and sunflower oil, absorption coefficient of some reference sample (at the very same wavelength) is required. The IR spectra of water $(12 \mu \mathrm{m}$ thick film) were studied [5] by means of conventional IR spectroscopy yielding $\beta=806 \mathrm{~cm}^{-1}$ at $3.39 \mu \mathrm{m}$. Using values for water from Table $1\left(\rho=1000 \mathrm{~kg} / \mathrm{m} 3, c=4180 \mathrm{~J} / \mathrm{kg} \mathrm{K}, \mathrm{k}=0.595 \mathrm{~W} / \mathrm{m} \mathrm{K}\right.$ and $\left.\mathrm{e}=1577 \mathrm{Ws} \mathrm{s}^{1 / 2} / \mathrm{m}^{2} \mathrm{~K}\right)$ with corresponding thermal diffusion lengths $(\mu=38.3$ microns at $30 \mathrm{~Hz}$ and 8.60 microns at $600 \mathrm{~Hz})$ one obtains a range of $\beta \mu$ varying from 0.7 at $30 \mathrm{~Hz}$ to 3.2 at $600 \mathrm{~Hz}$.

Table 1. Thermophysical data for water, oleic acid and sapphire: density $\rho$, specific heat $\mathrm{c}$, thermal conductivity $k$, thermal effusivity $\mathrm{e}$ and thermal diffusion length $\mu$ at two modulation frequencies.

\begin{tabular}{||l|c|c|c||}
\hline & water & oleic acid & sapphire \\
\hline$\rho\left(\mathrm{kg} / \mathrm{m}^{3}\right)$ & 1000 & $\approx 880$ & 3980 \\
$\mathrm{c}(\mathrm{J} / \mathrm{kg} \mathrm{K})$ & 4180 & 2300 & 752 \\
$\mathrm{k}(\mathrm{W} / \mathrm{m} \mathrm{K})$ & 0.595 & 0.230 & 32.8 \\
$\mathrm{e}\left(\mathrm{W} \mathrm{s}^{1 / 2} / \mathrm{m}^{2} \mathrm{~K}\right)$ & 1577 & 682 & 9900 \\
$\mu(\mu \mathrm{m})$ at $30 \mathrm{~Hz}$ & 38.3 & 34.5 & 340 \\
$\mu(\mu \mathrm{m})$ at $600 \mathrm{~Hz}$ & 8.60 & 7.76 & 76 \\
\hline
\end{tabular}

From Fig. 2, maximal value (1.99) for ratio of experimentally measured signals $\mathrm{S}_{\mathrm{C18:1}} / \mathrm{S}_{\mathrm{water}}$ is found at $600 \mathrm{~Hz}$. Upon substituting this figure and the values for C18:1 from Table 1 into eq.(1) one obtains $\beta \mu=2.16$ (for $\mathrm{C} 18: 1$ ). At $600 \mathrm{~Hz}$ thermal diffusion length is $7.76 \mu \mathrm{m}$ and hence $\beta=2782 \mathrm{~cm}^{-1}$ 
for pure $\mathrm{C} 18: 1$, cis at $3.39 \mu \mathrm{m}$. A similar computational procedure yields $\beta=1893 \mathrm{~cm}^{-1}$ for sunflower oil at $3.39 \mu \mathrm{m}$. Since an overall experimental error is small, the accuracy of obtained absorption coefficients depends in the first place on uncertainty of $\beta$ for water used here for calibration purposes.

The analytical potential of OW cell was studied next. The results from Fig. 2 were used to calibrate the OW cell (in terms of $\beta \mu$ scale) and another series of measurements performed with solutions of C18:1 in chloroform (no significant absorption at $3.39 \mu \mathrm{m}$ ) at two $(30 \mathrm{~Hz}$ and $600 \mathrm{~Hz}$ ) modulation frequencies; the results are shown in Fig. 3. Broken lines represent experimental curves obtained with $0 \%, 1 \%$ (by weight), $5 \%, 10 \%, 15 \%, 20 \%, 25 \%, 50 \%$ and $100 \%$ solutions while solid lines illustrate theoretical (eqs. (1) and (2)) variations of signal amplitude. A linear variation of $\beta \mu$ with concentration of $C 18: 1$ was assumed and values $\beta \mu=9.6$ (at $30 \mathrm{~Hz}$ ) and $\beta \mu=2.16$ at $(600 \mathrm{~Hz})$ were considered to correspond to a neat oleic acid (100\%) as determined above. When inspecting plots in Fig. 3 one is tempted to conclude that, contrary to predicted behaviour, optothermal signal saturates in a $25-100 \%$ concentration range. The apparent saturation is presumably due to the fact that even in relatively dilute chloroform solutions bonded $\mathrm{O}-\mathrm{H}$...O stretching vibration is not resolved from the $\mathrm{C}-\mathrm{H}$ stretching vibration at $3.39 \mu \mathrm{m}$ [6]. Below 10\% signal amplitude decreases (according to theoretical curves) down to intercepts with the signal levels corresponding to $0 \%$ concentration as seen in Fig. 3 . These extrapolated points define detection limits of $0.35 \%$ (at $30 \mathrm{~Hz}$ ) and $0.55 \%$ (at $600 \mathrm{~Hz}$ ) for oleic acid-chloroform solutions.

\section{CONCLUSIONS}

Unlike traditional infrared spectroscopy where thickness of the sample is a restrictive factor when dealing with strongly absorbing samples, the effective pathlength in OW approach is determined by control of a modulation frequency. Optimization of $\beta \mu$ by controlling modulation frequency is essential for quantitative interpretation of results. The absorption coefficients for oleic acid and sunflower oil at $3.39 \mu \mathrm{m}$ are $2782 \mathrm{~cm}^{-1}$ and $1893 \mathrm{~cm}^{-1}$, respectively. These values agree well with those obtained with FTIR analysis for same samples but of known thickness $(10 \mu \mathrm{m})$. Data collected in studies with $\mathrm{C} 18: 1 / \mathrm{CH}_{3} \mathrm{Cl}$ solutions suggest $0.35 \%$ detection limit (at $30 \mathrm{~Hz}$ ). Failure of $\mathrm{C} 18: 1$ to follow Lambert-Beer's law as observed in this study is most likely due to a spectral overlap of C-H and $\mathrm{O}-\mathrm{H}$.......

Acknowledgments. One of authors, M. Chirtoc gladly acknowledges the receipt of fellowships from NWO (Dutch Organization for Scientific Research, The Hague, The Netherlands) and from Humboldt Foundation. Credit is given to Mees Schimmel and Kees Rijpma who provided illustrations and to Mrs. Minie Langenveld for taking meticulous care of the manuscript.

\section{REFERENCES}

[1] Silverstein R.M., Bassler G.C. and Morrill, T.C., Spectrometric identification of organic compounds (John Wiley \& Sons, New York, 1981).

[2] Helander P., Measuring Science and Technology, 4, (1993) 178-184.

[3] CRC Handbook of physics, $63^{\text {th }}$ Edition (Chemical Rubber Company, Chicago 1991).

[4] Fatty acid data book, $3^{\text {rd }}$ Edition (Unichema International, Gouda 1992).

[5] Coates J.P., European Spectroscopy News 16, (1978) 25-31.

[6] O'Connor R.T, Field E.T and Singleton W.S., The Jour. of the Amer. Oil Chem. Society 28, (1951) 154-161. 